\title{
Designing a Strategic Model to Adapt Lean Production System for Toyota Company of Higher Education in Iraq and Measuring Its Impact on University Learning
}

\author{
Dr. Hani Fadhil Jumaah Al-Shawi', Dr. Mohammed Hussein Manhal2 \\ ${ }^{1}$ Assistant Prof Dr. in Accounting Department, Shatt Al-Arab University College, Basra, Iraq \\ ${ }^{2}$ Prof Dr. in Administration Department, in College of Administration \& Economics, University of Basra, Basra, Iraq \\ Email:dr.hanishawi@gmail.com,Manhal_Manhal@yahoo.com
}

How to cite this paper: Al-Shawi, H.F.J. and Manhal, M.H. (2020) Designing a Strategic Model to Adapt Lean Production System for Toyota Company of Higher Education in Iraq and Measuring Its Impact on University Learning. Open Journal of Business and Management, 8, 902-922. https://doi.org/10.4236/ojbm.2020.82056

Received: January 20, 2020

Accepted: March 23, 2020

Published: March 26, 2020

Copyright $\odot 2020$ by author(s) and Scientific Research Publishing Inc. This work is licensed under the Creative Commons Attribution International License (CC BY 4.0).

http://creativecommons.org/licenses/by/4.0/

\begin{abstract}
The idea of the current research is based on the possibility of developing the quality of the higher education environment by adapting the concern of "value-oriented production" which depends on removing activities that hinder the teaching, student and administrative performance in Iraqi universities. The research aims to rethink the improvement of added value based on the concept of lean production through a main hypothesis, "There is a possibility to adapt the lean production system model for Toyota company or (T.P.S.M) to the higher education environment." The research has reached some of the most important conclusions, "It is possible to use the lean production system according to Toyota to improve the quality of Higher education in Iraq."
\end{abstract}

\section{Keywords}

Higher Education Environment, Value Oriented Production, Lean Production, Toyota for Lean Production System Model or (T.P.S.M), Quality Management

\section{Introduction}

The success of the most prominently prestigious universities in the year is related to efficient practices for managing the quality of university education in a manner consistent with the educational trends emphasized by those universities and the present intellectual and technical stage of development to develop the intellectual capabilities and skills of the learner.

This research has come to present a vision that deals with the systems, the 
teacher and the learner in our educational institutions in order to improve the educational process, system, content and individual, through the need to review the prevailing traditional educational applications in our institutions.

And how to formulate a knowledge plan for the available specializations, to make way for the application of the concept of lean production and get rid of the loss in education, and in order to circulate this knowledge to meet "the requirements of the times and society, the effort of this study was focused on two successive roles:

First: Investigative or exploratory through documenting the views of the parties to the educational practice university leadership and faculty.

As an attempt to monitor the downsides of current practices and replace them with the positives of the proposed practices.

The second: An experimental proposal to present an intellectual proposal that achieved success "in countries that embraced creativity as a way" for its advancement and progress in an attempt to emulate and experiment it in the field of higher education.

As for the methods of this study, it was in personal interviews to monitor the justifications for writing this effort, and to analyze the content through readings in the literature of education and dive into the depths of philosophy that made Toyota an example for anyone trying to succeed in his field of research in search of the possibility of applying that philosophy in the educational institutions subject to testing and the study.

The coverage of this study was as follows:

The first aspect: is divided into two parts, the first section focuses on the methodology of the study and the second section focuses on the theoretical framing of it and is represented in listing all of the available literature on clarifying the details of lean production and its pros and requirements.

The second aspect: presenting the stages of field application in higher education institutions in (Basra University, Technical Education Authority, Shatt Al-Arab College) and analyzing the available data to convert it into information and results.

The third aspect: The conclusions and recommendations of this study.

Finally, I hope that this research will receive the appropriate attention from those responsible for the educational process in the Ministry of Higher Education and the relevant authorities to serve the march of quality education in the country. God bless.

\section{Methodology of the Study}

The methodology of the study was presented through nine paragraphs, and each of these paragraphs will be clarified as follows:

\section{First: The study problem}

Failure to adopt various practices in improving the performance of the university education system in our country will mislead many facts that disclose the 
truth about the level of thought and knowledge and its circulation.

And reviewing the prevailing educational practices in higher education in general and in universities in particular, and all that is associated with it from other institutions practicing the same activity, to be considered something that needs more attention in line with contemporary trends in education, because of this has a prominent role in correcting the trends.

This has aroused the researcher's interest and their amazement about the lack of attempt by the authorities concerned with the subject in testing and adopting advanced methodologies in evaluating and improving the quality of the performance of their universities or their education Institutions.

Accordingly, the problem of the study was limited to trying to identify the most important factors that cause wasting energies in higher education, diagnosing them and determining their causes, then adopting modern scientific methods that represent experiences of advanced countries in industrial fields.

Represented by the variables of the Toyota production system model or (T.P.S.M) which is called lean production, inspired by the ideas of Japan's creative pioneer (Taiiji Ohno).

Where the researchers believe that a part of the problem of waste in the higher education system in Iraq can be solved by adopting these ideas after their adaptation and for research purposes, the problem is formulated through the following questions:

1) Can graceful production style practices be applied in the higher education system in Iraq?

2) Can Toyota's (T.P.S.M) production model be adapted to the Iraqi higher education environment?

3) Does the application of lean production practices and the TPS model in the universities and institutes of the Iraqi Technical Education Authority lead to achieving added value for the final product represented by the educational service for students? Are our universities ready to accept these practices?

\section{Secondly: Importance of the study}

The importance of the study emerges from the importance of the subject of lean production and its consistency with the conditions of the current stage in which the global economy passes in general and the local in particular, as a result of the conditions of the global financial crisis and the spread of its effects at all levels and sectors, and not the education sector without a harbor "from it, in an attempt to get rid of the losses and wastes that cause waste". Resources of all kinds and removing everything that would delay the educational process in terms of "content".

Perhaps universities are the most responsible from other industries in preparing studies that can reflect positively on improving the quality of the field that they practice, as it supplies all sectors with the efficient talents they need in terms of their outputs from graduate students who represent inputs to other industrial organizations that promote the prosperity of the economy. And his recovery in 
the country is if the entrance is of good quality and knowledge in behavior, practice and professionalism, and if the universities are not accommodating for their pioneering role in these contributions, then this is considered a "serious" matter that must be paid attention to and an attempt to draw its attention to.

In recent times, the outputs of human education from graduates of initial studies in the universities of the country began to deviate from the aspirations of the beneficiary parties and what they require in meeting their various needs and what their work requires in terms of technical skills and knowledge commensurate with the outputs of developed global industries to compete with them and dispute with them on investment in various fields and businesses to seize and seize opportunities. Therefore, we seek our humble role to reduce or avoid it and work to reduce human and material losses by increasing the awareness of workers of the importance of detecting them and recording deviations in their performance voluntarily so that the educational institution gets the right It is possible to analyze and arrive at the root solutions for these failures, so the importance of the study is demonstrated by the following:

1) Contributing to identifying the most important factors that lead to failure to improve quality in education.

2) In response to the increased interest in evaluating university services and attempts to reduce failure and failure in the field of university education along with technological development.

3) The current study may contribute to enriching the knowledge side in this field.

\section{Thirdly: Objective of the study}

This study aims to:

Carrying out a theoretical review of the resources available to researchers in order to prepare a theoretical framework for it and to make an academic contribution regarding study variables, which is one of the renewable topics that are associated with educational institutions throughout their life;

Knowing the nature of the graceful production practices in place at the source of their existence and the home of Toyota, and then trying to adapt those practices to the higher education environment;

Submitting proposals to local educational institutions in light of the results of the research;

Highlighting the importance of the role of the process of streamlining production that did not receive the required attention by the specialists in our university educational institutions until the moment (according to the researchers' knowledge) and considering it an important part of improving the quality of that service.

\section{Fourthly: Style of study}

The basic method of this study is based on a review of the following:

1) The researchers will review the philosophy and process of graceful production by looking at the available scientific efforts in libraries in the literature re- 
lated to the subject of study in periodicals and Arab and foreign books.

2) The study will test two phases:

-The first: The extent to which the TPS model can be adapted to a higher education environment.

-The second: The extent of response to the application of the philosophy and process of lean production in our educational institutions and the effect of this on improving the quality of the educational service to reach scientific conclusions and raise them to the authorities concerned with developing the quality of the educational sector.

\section{Fifthly: The limits of the study}

The study is determined by the following:

1) Spatial limits: Study is limited to Basra University as a model for public universities and the technical college as a model for the Technical Education Authority and the Shatt Al-Arab College as a model for the National Education Authority.

2) Time limits: The period of study extended from the beginning of August 2016until the end of November of 2019.

\section{Sixthly: Study variables}

In light of the problem of the study and to achieve its goals, a proposed plan has been built to diagnose the effect of applying the Toyota production system or (TPS) philosophy and lean production practices after adapting it to a higher education environment in the quality of university performance, the following is the hypothetical research scheme (see Figure 1) that illustrates this scheme and has been shown to include the two main variables in the research, namely:

The first variable:

The independent variable, which is (the lean production system in higher education to reduce the seven wastes) reducing the overproduction, reducing the transfer time, reducing the inventory, reducing the movement, reducing the

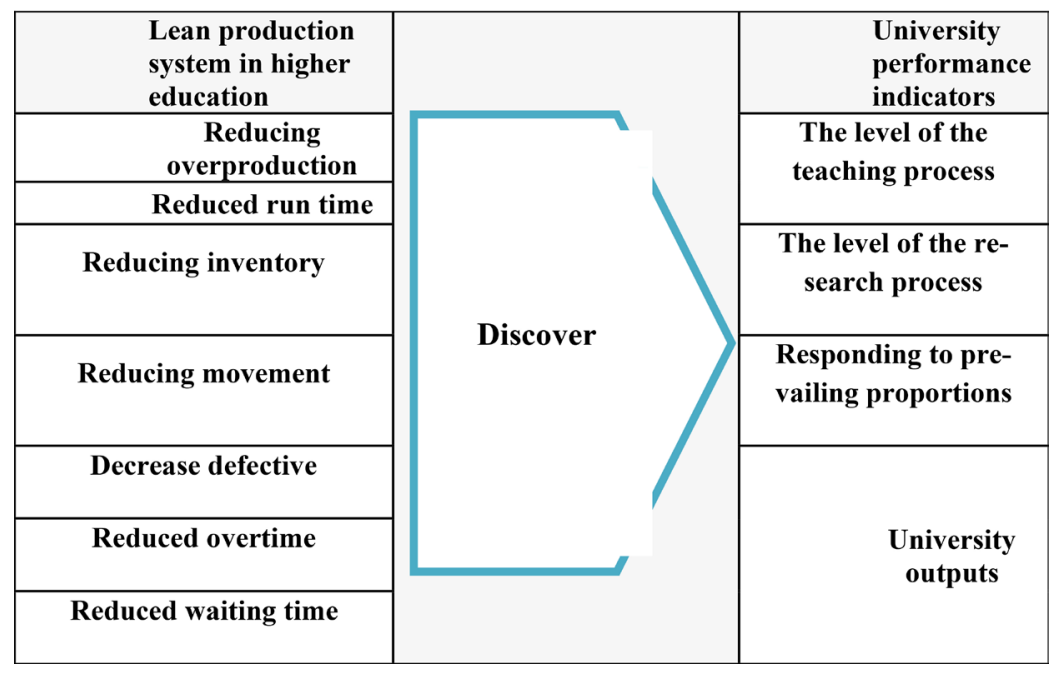

Source: Sample prepared by the researcher.

Figure 1. Default study model. 
defect, reducing the overtime, reducing the waiting time, which is the voluntary side of TPS model to a higher education environment.

The second variable:

The dependent variable, which is represented in the quality of university performance.

The University performance indicators:

1) The level of the teaching process

2) The level of the research process

3) Responding to prevailing proportions

4) University outputs

\section{Seventh: The default study plan}

Eighthly: Study hypotheses

The study is based on one main hypothesis that "There is a possibility to adapt the Toyota's production system or (TPS) to the higher education environment and there is a significant impact of the (TPS) philosophy on the quality of the educational service in higher education."

From this main hypothesis, a set of sub-hypotheses emerges as follows:

1) There is a significant, destructive effect between TPS philosophy, lean production practices and educational service delivery systems in universities.

2) There is a significant moral effect between TPS philosophy and lean production practices to improve the quality of the absorption process among university students.

3) There is a significant effect between (TPS) philosophy and lean production practices that contribute to raising the efficiency of faculty performance in universities.

\section{Ninthly: Study scale}

The scale of study was built on the basis of the original Toyota model, to complement the requirements for constructive implementation to implement lean production practices in our university educational institutions.

\subsection{The Second Aspect of the Study: Theoretical Framework of the Study}

First: literature review and the story of the lean production Toyota system (TPS)

The efficient management and control of production operations are increasingly becoming complex and there is an inherent need to improve the control of manufacturing processes in the face of unexpected disruptions. These disruptions, such as quality problems, resource breakdowns, material unavailability, order changes and rush orders, can cause significant impact on the performance of a production system and can also lead to delay in delivery dates, impacting customers and wider business functions [1].

\subsection{The Philosophical Foundations of Lean Production}

The most fundamental ideas on which lean industrialization focused are almost 
those that relate to the seven wastes or losses that do not add value to the product and which we will address in the following narration: -

\subsection{The Seven Wastes}

The philosophy of Toyota production system (Tps), which adopts the concept ( $(3 \mathrm{mu})$, found the basis "to get rid of waste and add value to the product". In this paragraph, we will define the types of waste that have affected ohno insomnia. One of the basic steps in the grace and the Toyota production system (Tps) is to determine what steps add value and what they do not add.

-By classifying the activities of the process into these two classes, it is possible to start with the improvement activities of the previous one (which adds value) and get rid of the suffix (which does not add value).

-The work that adds value is separated from waste, and accordingly, waste can be divided into (needs that must be eliminated, but it does not add value), that is, to waste, waste and exchange.

The clear identification of works that do not add value, distinguishes between waste or real work, it is important to distinguish between the assumptions and beliefs behind the current work.

The phrase "Learning To see" that was raised as a logo at Toyota came from improving the ability to see the waste that was not previously diagnosed.

And many believe that the development of this ability is through (travel to Japan) to visit (TOYOTA) to see the difference between its operations and those operations subject to continuous improvement for thirty years under the TPS system.

(Shigeo Shingo) TPS finder assistant note that (the last turn in the workflow is just a movement to rest), (and rediscovering this waste) enabled him to reduce the conversion time used to cut (the car body) to less than $3 \%$ than it was in the 1950s.

Note that this period allowed all processing services to adopt that new capacity and utilized the transfer time (which was previously wasted) in multiple optimization processes.

The following seven wastes commonly identify and classify wasted resources and have been identified by the chief engineer of TOYOTA (Taiij Ohno) as part of the production system at Toyota (TPS):

1) Overproduction

Overproduction occurs at any time more resources are brought into production than are required to be delivered to the customer.

For example: A large production payment, a longer transfer time, exceeding the quantity requested by the customer.

In order to improve productivity, what is required is to produce more than the customer's need, that additional parts are stored and not sold, and excess production (surplus production) is wasted (Muda): It is a Japanese word It is one of the three types of waste (Mura, muri, muda) according to Japanese philosophy and These three words $(\mathrm{Mu})$, which are widely used in Japan, have been 
recognized as a source of the Product Improvement Initiative) because it generates other types of waste, especially inventory.

So what is Muda?

Moda means any excess activity (waste) or any obstructions to the flow of the activity.

$$
\begin{aligned}
& \text { Activity }=\text { Muda }+ \text { Work. } \\
& \text { Expenses }=\text { cost }+ \text { waste. }
\end{aligned}
$$

This means that in every activity there are expenses and for every action there are costs related to it.

-And that any expenses on (MUDA) are wasted.

-Thus, (Muda) less = a happier customer (due to the effect on quality, cost, delivery, of the good or service).

Also (overproduction) increases the amount of space required for storing raw materials as well as manufactured products, and requires a protection and preservation system.

2) Transportation

At the time the product is transported, it is subject to damage, loss, delay, and slaughter

-At the same time, this is a cost that does not add value.

-And transportation does not make any conversion on the product that is expected to be paid by the consumer.

3) Inventory

Inventory: When it is in the form of (raw materials, semi-manufactured goods (Wipe) in progress, or finished goods), it represents capital that does not generate income for the producer or consumer, and each of the three paragraphs if it is not effectively implemented to add value is wasted.

4) Motion

When compared to transportation, the movement refers to the product, worker, or equipment.

This is why it is important in terms of damage, wear and tear, safety, and it also includes fixed assets and expenses that arise from the production process.

5) Defects

Whenever there is defective (defective parts), this means waste "and additional costs that arise from the restoration of that part, the rescheduling of production, etc.".

6) Overtime (Overtime) Over-Processing

Additional operation occurs by working on a specific piece more than what the customer requires, and this includes the use of tools of the most type (accuracy, complexity, or price) which really requires the work.

7) Waiting

When goods are not during the process of transportation or operation, they are waiting and in traditional operations a large part of the product's life cycle is spent on waiting until its completion (work on it). 


\subsection{Classified by Toyota Motor Corporation [2]}

And each of these seven wastes can be found in production processes, whether manufacturing or service, although these are Philosophy has mainly evolved in Japanese auto production plants (specifically at Toyota Motor Company), but its applications today have expanded to include the aircraft industry and many other industries. It has also included service areas such as banks, hospitals, health services, and universities in the West, which have included within their management programs the applications of these. Philosophy in the late nineties to develop administrative work and Hussein educational outputs in its colleges, and provide excellent services to students and workers in line with the requirements of the market and the requirements of excellent academic work. While our educational institutions were breathing their lasts due to the severity of the effects of the wars, woes and siege left by and the previous regime fought and paid for by the student, the professor and the movement of knowledge that completely paralyzed until the foundations of the quality of education collapsed and the universities continued to mourn and aspire to the severity of the chaos and neglect suffered at that time and the preoccupation of the tyrant With the manufacture of weapons and explosives, they have turned to the outcome of the march of education in Iraq in that period of underdevelopment of the levels of university education activities in the West and the unique experiences that they applied that produced amazing and incredible results.

\section{The Differences between Traditional Production and Lean Production}

Before you begin to format your paper, first write and save the content as a separate text file. Keep your text and graphic files separate until after the text has been formatted and styled. Do not use hard tabs, and limit use of hard returns to only one return at the end of a paragraph. Do not add any kind of pagination anywhere in the paper. Do not number text heads-the template will do that for you.

Finally, complete content and organizational editing before formatting. Please take note of the following items when proofreading spelling and grammar:

The result of Ohno's efforts is summarized by a set of practices that distinguish lean production from traditional and which can be summarized by [3] in Table 1.

\subsection{Lean Production Process}

In the previous paragraph, we reviewed the philosophical foundations and the fundamental idea of lean production, and in this paragraph we will address lean production as a process within the implementation process and not just an idea.

The concept

This term can be reviewed with what came from the literature that attempted to delve into, as follows: 
Table 1. Shows the points of differentiation between the two concepts.

\begin{tabular}{lll}
\hline Practices & Conventional production system & (L.P.S) Lean production system \\
\hline $\begin{array}{l}\text { Inventory } \\
\text { Preparation }\end{array}$ & Big & Small \\
the quality & $\begin{array}{l}\text { Slow to repeat } \\
\text { Statistical methods are used to diagnose defects in order The quality of the product from the first time } \\
\text { to recycle them }\end{array}$ & Fast and frequent \\
Volume of production flow or batch & Big & Small \\
Management & With orders & Participatory and unanimous \\
Skills of workers & Single and monotonous job & Multiple and renewable functions \\
the suppliers & He viewed them as enemies & They are seen as friends and participants \\
Delivery & Little & Abundant \\
Connection & Vertically and mainly from top to bottom & diverse \\
Consultation & Limited & Wide \\
\hline
\end{tabular}

Source: [3]. 


\subsection{The Basics of Lean Production}

The basics of lean production are as follows:

1) Reducing the preparation time, the preparation time is the process in which the conditions of production or manufacturing are changed from that work in which a specific product is produced to a situation in which another product is produced and including stopping the production of the current work and preparing the conditions necessary for the production of the next work, and from the benefits Reducing setup time.

2) Flexibility, as we can now produce orders as desired by the client and without worrying about stock inflation.

3) Fast delivery of orders, as production in small quantities means less preparation time and thus less waiting time for the customer.

4) Better quality: When inventory decreases, the errors and defects resulting from the increase in inventory will decrease, and using the method of rapid change, preparation errors are less for the new product.

5) Higher productivity.

6) Make all production processes run smoothly.

The philosophy of lean production cannot succeed in a workplace full of chaos or a lack of organization, which is one of the causes of waste, waste and preoccupation with the unnecessary excess movement in research and non-regulation of the tools used by workers in the completion of their work and thus delaying the time of access to them so creating a work environment with the basic conditions Production is the first step in establishing a cell to improve the ideal and graceful manufacturing place. Employees must adhere to the principle of simplifying the work environment by making it safer and more effective, reducing materials that do not belong to the workplace, and freeing occupied spaces and spaces from materials other than Necessary, such as broken, damaged, and unused tools, hardware, and redundant raw materials. On the other hand, for improving productivity and reducing waste, organizations have been implementing lean principles for some time In order to achieve this, organizations have been moving towards Just-in-time manufacturing system and implementing make-to-order systems. One of the key steps in implementing a lean system is to reduce waste by limiting inventory levels.

However, when unexpected disruptions occur, the impact of these unanticipated events will have dire consequences and will therefore need careful consideration when leaning activities are considered.

\subsection{Lean Production Objectives}

The goals of lean production are as follows: see [9].

1) Improving quality in order to intensify competition and maintain the organization's market share, therefore companies must be aware of the requirements of their customers and their desires, and design processes in a manner that suits their aspirations and is consistent with and consistent with their tastes. 
2) To get rid of losses, waste or losses that do not add value to the product or service.

3) Reducing time, reducing cost, and reducing waste in more effective ways of performance.

4) Reducing the total cost of production on demand and not storing products and early delivery to customers.

\section{**Lean production features}

The graceful production is characterized by

1) An excellent level of quality, from the first time and every time, through relentless pursuit and reaching the zero point in the defects, and the detection of problems and dilemmas in their places.

2) Minimizing wastes and eliminating all operations that do not lead to an increase in the value or belong to the product's network, while making the most of resources (material, human, and land).

3) Continuous development-reducing costs-improving quality-increasing productivity and sharing information.

4) On-demand production, not by dumping, through prolific production.

5) Flexibility, i.e. production capacity in different groups and types, distinct and fast, without sacrificing production efficiency by producing smaller quantities.

6) Building and maintaining long-term relationships with material suppliers by sharing information about costs and risks.

And we can explain in Table 2 the $\left(14^{\text {th }}\right)$ Management Principles of Lean Manufacturing [10].

\section{The Third Aspect of Study: The Process of Adapting the TPS Model to a Higher Education Environment}

Given the importance of the growing higher education system in Iraq, the return

Table 2. Explain the $\left(14^{\text {th }}\right)$ lean production or manufacturing principles.

1. Base decisions on a long-term philosophy, even to the detriment of short term financial targets.

3. Organization of single piece flow processes to identify problems.

5. Creation of a culture of immediate quality problem solving at first try.

7. Utilization of visual control to ensure no problem remains hidden.

9. Training of managers who know the work perfectly, live the philosophy and teach it to others.

11. Respect for the network of partners and suppliers, by encouraging them and helping them to progress.

13. Consensual decision-making by taking the time necessary, by examining all the options in detail, followed by rapid application of the decisions.
2. Utilization of pull systems (flow triggered only by client orders) to avoid excess production.

4. Production smoothing.

6. Standardization of tasks as the basis of continuous improvement and employee empowerment.

8. Utilization of reliable technologies, tried and tested through time.

10. Training of exceptional individuals and teams who apply the philosophy of your enterprise.

12. Interaction with the field to clearly understand the situation.

14. Systematic reflection and continuous improvement. 
of its cadres and the thinking minds to the warm embrace of the homeland and to try to materialize the experiences of the countries of the world and adapt them in the field of higher education and in line with the current stage, which are characterized by the appearance of features and signs that may affect the work of all sectors, and the role in Cultural awareness and the great social responsibility that the universities of Iraq hope and implement, and an expression of "our belonging". This physiological team (from abroad and inside) about these ambiguous circumstances and the need to preserve the financial, material, and intellectual higher education resources from waste, excess, loss, and immigration. The researchers generated the idea of streamlining the energies of this system by preserving its efforts that are sometimes spent "in other than its correct paths and assigning members of its staff". Teaching tasks that do not touch their specialties, such as committees, administrations, monitoring of boring and repeated tests and statistics carried out by some bodies, etc. and trying to get rid of them by adapting the (TPS) system of Toyota Motor Company to the higher education environment in Iraq and starting from the Japanese society's concepts in vaccinating the local system with this concept for the similarity in the conditions and crises that passed on the two societies.

For the boring and abhorrent wars that took place in the two countries and the presence of the challenging spirit of the human element.

In both countries, with a conservative value-based environment and educational system in place, which is a fertile element and environment for the application of quality concepts on the one hand and a commitment to norms and ethics in performing work, the latter community needs to be more educated.

About loyalty and sincerity in the work that is available to a limited degree while the members of Japanese society shine By giving the finest examples in it, and he did not come out of the blue, he was criticized by the sacrifices of the Shinto pilots during their dedication to performing the military duty in the global war in which Japan lost, in front of NATO forces, who struck the finest examples of heroism, courage and sacrifice until they reached the level of immortality in the minds of some Japanese and lived in their minds and the contents of their lives up to the moment, and they are not more courageous than the Iraqi individual known also is steadfastness, impulsiveness and dedication in doing the homework, but this is what he inherited and cultivated by the grandparents only and not through awareness.

Therefore, the responsibility for disseminating it rests with intellectuals, scholars and educators, and researchers hope that everyone will do so. The recruitment process will begin with a review of the main justifications for it, which is lean and then improve university performance, and for the sequence to be logical.

\subsection{Quality in Higher Education}

Quality in education has been defined by [11] as "establishing a distinct perfor- 
mance culture in such a way that everyone works continuously to fulfill customer expectations and perform the right work in a correct manner to achieve the required quality."

As for Rhodes, he defined it as a management strategy process that is based on a set of values and derives its movement energy from the information in which we are able to employ the talents of the educational staff and invest their intellectual capabilities in various levels of organization creatively to achieve the continuous improvement of the organization. It is noted in this definition that there are several focus points, the most important of which are:

1) Focus on the strategic dimension;

2) Focus on the values that the individuals responsible for creating quality believe in;

3) Focus on employing and investing the intellectual talents of the teaching staff;

4) Achieving continuous improvement, which can be determined at the beginning, and the end cannot be determined, as it is characterized by continuity.

It is also deduced from the previous definition of Rhodes that the teachers play a large role in determining the level of education quality in the university to a large extent for the following two reasons:

1) The administrative leadership of the university is mainly from the faculty and therefore they are able to fully interact with the course of education at the university.

2) University teachers are distinguished by many advantages that differ from those of others, such as teachers in primary studies and others. They are the decision-makers in defining the curriculum, teaching methods, and complete independence in assessing students.

This leads us to believe that the degree of success/failure of the quality in the university largely depends on this aspect of the teaching staff as one of the pillars of the basic educational process.

\section{$* * *$ The justifications for adopting quality in education}

There are many reasons for adopting quality in education, of which the most important are the following [12]:

1) Improving the outputs of the educational process.

2) The comprehensive technological revolution based on the scientific and knowledge flow represents a challenge for the human mind, which made societies compete in raising the qualitative level of their educational systems.

3) As the student is the target and axis of the process, he must be satisfied as a primary customer in the educational process.

4) The necessity of making improvements in the educational process in an organized manner through continuous data analysis.

5) Investing the capabilities and energies of all the teaching staff in the educational process. 
6) A method for transferring authority to the teaching staff of the institution while maintaining central administration.

7) Create effective communication at the horizontal and vertical levels.

8) Total quality has a special management culture. This requires changing the pattern of managerial organizational culture in the educational institution. This means changing the prevailing values and behavior to help achieve total quality.

9) Change the administrative style to participatory management.

The image of the quality of university education is not completed according to our belief, except by activating the university considerations below:

1) Understand the relationship between the teacher and the learner.

2) The role of the teacher in the educational process.

3) The learner's cognitive abilities and behaviors.

The above has been our incentive to adapt the ideas of (Ohno Taiiji) and the philosophy of TPS to the higher education environment, in order to achieve a "great" success in the industrial environment.

\subsection{The Fourth Aspect of the Research: The Applied Side of Adaptation}

First the process of adapting the Toyota TPS model to the higher education environment in Iraq.

To adapt waste from the manufacturing environment to the university education environment, we suggested Table 3.

In order to implement the voluntary model, it is necessary to adopt methodological scientific mechanisms that assist in implementation step by step and to complete the benefit of the form of induction. A second procedural guide, "as follows:-

Base mechanism summarizes Continuous or sustainable improvement And last what improved With the following:

How do you notice?

1) Go to the work site ((-Gemba-Japanese concept)).

2) Clean yourself.

3) Do not sit in a place.

4) Do not ask for ideas.

5) See look first for waste. (Muda) in Japanese concept.

6) Then look out for ((Mura)) in Japanese concept.

And according to (Christina, and others) Lean production is a strategy or philosophy that promotes the use of practices, such as [13]:

- kanban-total quality management (TQM), to minimize waste-and just-in-time (JIT)—and enhance firm performance.

Thus, the implementation of lean production practices is expected to result in improved operational outcomes, such as lower inventories, higher quality, and shorter through put times, which, in turn, should improve the performance by 
Table 3. The process of adapting the seven wastes from the manufacturing system to the university service system.

\begin{tabular}{|c|c|c|c|}
\hline Seven wastes & $\begin{array}{l}\text { In the commodity } \\
\text { manufacturing system }\end{array}$ & $\begin{array}{l}\text { In the higher education } \\
\text { system in Iraq }\end{array}$ & $\begin{array}{l}\text { The proposed agility process } \\
\text { in the higher education system }\end{array}$ \\
\hline Overproduction & $\begin{array}{l}\text { Insert more resources into the } \\
\text { production process than required }\end{array}$ & $\begin{array}{l}\text { Introduce more curricula into the } \\
\text { teaching process than the specialization } \\
\text { the student needs and include it in its } \\
\text { contents without meaning, such as } \\
\text { human rights, freedom and democracy. } \\
\text { Rights and freedoms do not know, are } \\
\text { not given, but are taken away from their } \\
\text { usurpers }\end{array}$ & $\begin{array}{l}\text { Reconsidering the process of determining the } \\
\text { curricula that are appropriate to the specialty } \\
\text { and canceling all the curricula that do not add } \\
\text { scientific value to the student such as (freedom, } \\
\text { rights, computers) }\end{array}$ \\
\hline Transportation & $\begin{array}{l}\text { The systematic transfer process } \\
\text { exposes the commodity to } \\
\text { damage, loss, delay, failure and } \\
\text { breakage }\end{array}$ & $\begin{array}{l}\text { The teacher moved from his room to the } \\
\text { location of the classroom or the } \\
\text { laboratory, if he was far away, which } \\
\text { might cause his leg to be broken by using } \\
\text { a lot of stairs, especially if he was old }\end{array}$ & $\begin{array}{l}\text { Using the electronic linking of the electronic } \\
\text { models for the halls (blackboards) in a way that } \\
\text { achieves the shortening of time and the lack of } \\
\text { transmission of the teaching, but the professor } \\
\text { gives the lecture while he is in his room to many } \\
\text { halls and the related laboratories or make the } \\
\text { classrooms very wide "and the setting of } \\
\text { monitoring cameras in the performance of the } \\
\text { exams linked to a monitoring unit in the } \\
\text { university }\end{array}$ \\
\hline Inventory & $\begin{array}{l}\text { When materials are stored (raw, } \\
\text { semi-finished, semi finished, or } \\
\text { finished goods) It represents } \\
\text { capital that does not generate } \\
\text { income for the product or } \\
\text { customer and is considered wasted. }\end{array}$ & $\begin{array}{l}\text { Store old records, outdated books and } \\
\text { exam books }\end{array}$ & $\begin{array}{l}\text { Using paper scrap and returning it to the paper } \\
\text { mills to make a paper pulp for the university to } \\
\text { re-manufacture it again and deducting the cost } \\
\text { of raw materials from it, which can be returned } \\
\text { instead of burning after a prescribed period, but } \\
\text { destroying it first is not burning }\end{array}$ \\
\hline the movement & $\begin{array}{l}\text { The movement of the worker in } \\
\text { the factory without work }\end{array}$ & $\begin{array}{l}\text { The movement and silence of the } \\
\text { university employee in excess during } \\
\text { working hours that do not add value to } \\
\text { work (such as food, tea, smoking, speech, } \\
\text { and the use of regular stairs and many of } \\
\text { them, as well as the additional movement } \\
\text { of wiping the blackboard for more than } \\
\text { once during the lecture time }\end{array}$ & $\begin{array}{l}\text { The use of electronic models reduces the } \\
\text { additional movement and instill values of } \\
\text { responsibility, honesty and persistence And } \\
\text { punctuality and duties }\end{array}$ \\
\hline Defective & $\begin{array}{l}\text { Damaged goods that violate } \\
\text { production and consumption, } \\
\text { which require the return of } \\
\text { additional costs }\end{array}$ & $\begin{array}{l}\text { Mistakes of university work decisions, } \\
\text { such as shocking the return of the } \\
\text { Mistakes of university work decisions, } \\
\text { such as shocking the return of the } \\
\text { chimney, their restrictions to study seats, } \\
\text { working with the loading system with } \\
\text { one, two materials, and third-floor exams } \\
\text { (which may lead to the disappearance of } \\
\text { the idea of success and failure and } \\
\text { replacing it with cognitive decay) and } \\
\text { spending on it efforts and funds without } \\
\text { success, as well as condoning some } \\
\text { attempts to cheat as deliberate } \\
\text { procrastination to deal With it, which } \\
\text { leads to the transitional student moving } \\
\text { to advanced stages, as is the case with } \\
\text { good students, to set an example for other } \\
\text { abusers and distort the march and } \\
\text { achievements of competent cadres in } \\
\text { Iraqi higher education }\end{array}$ & $\begin{array}{l}\text { Immediately stop "from interest in } \\
\text { non-distinguished groups, and the researchers } \\
\text { denounces such ideas and we should not forget } \\
\text { the talented students because they are the leaders } \\
\text { of tomorrow, and use the immediate } \\
\text { reinforcement of their accomplishments, } \\
\text { motivating the first students and rewarding } \\
\text { them by accepting higher studies and } \\
\text { suspending their names with honor boards } \\
\text { instead of motivating the losers and making } \\
\text { them feel that they are spoiled by the higher } \\
\text { authorities In the ministry and accountability of } \\
\text { the foundations of this destructive miserable } \\
\text { culture of science that discourages success and } \\
\text { trying not to fall as a victim of pressure groups } \\
\text { and get rid of the concept of quantum in } \\
\text { education to the concept }\end{array}$ \\
\hline
\end{tabular}




\section{Continued}

\begin{tabular}{|c|c|c|c|}
\hline Overtime & $\begin{array}{l}\text { Exaggeration of working in a } \\
\text { certain part more than another } \\
\text { part, such as repeating a process } \\
\text { more than once on the same part } \\
\text { of the work (cutting, welding, } \\
\text { fastening, coating, etc.) }\end{array}$ & $\begin{array}{l}\text { Restoring the teaching process for hostile } \\
\text { students after their promotion for more } \\
\text { than once is considered an additional } \\
\text { work. Also, teaching study materials does } \\
\text { not add value to the student, such as } \\
\text { computers, human rights, freedom and } \\
\text { democracy. These lectures exhaust both } \\
\text { the student and the teacher, as well as } \\
\text { halls, benches, laboratories, etc. }\end{array}$ & $\begin{array}{l}\text { Review the basics of dealing with these cases by } \\
\text { opening computer courses during the holidays } \\
\text { and not during the academic time. Benefiting } \\
\text { from the principle of education for the future }\end{array}$ \\
\hline Waiting & $\begin{array}{l}\text { Waiting time (lost time) between } \\
\text { one process and another, for } \\
\text { example (from cutting to welding } \\
\text { to painting or due to the spacing } \\
\text { of machines, as well as waiting for } \\
\text { material returns from the goods } \\
\text { until the product matures and } \\
\text { testing it from the customer and } \\
\text { deciding to return the purchase } \\
\text { ball after using it and trying it out } \\
\text { for it }\end{array}$ & $\begin{array}{l}\text { Waiting for the professor (while counting } \\
\text { absenteeism and attendance) and the } \\
\text { student for time-spaced classroom classes } \\
\text { due to not studying or not scheduling } \\
\text { quotas production well/Waiting for a } \\
\text { response to constructive proposals from } \\
\text { the reference series in higher learning } \\
\text { which leads to the missed and missed } \\
\text { opportunity to seize it in its season or } \\
\text { peak time (opportunity Lost) }\end{array}$ & $\begin{array}{l}\text { Take advantage of the numbered seat style to } \\
\text { quickly record attendance and absence, not to } \\
\text { waste academic time, make use of the art of time } \\
\text { management, save time and effort by paying } \\
\text { attention to scientific priorities and place them } \\
\text { at the forefront of time and not waste them by } \\
\text { placing them in a distant time, i.e. when the state } \\
\text { of boredom and fatigue reaches the student and } \\
\text { eliminate time gaps in Quotas and benefit from } \\
\text { teaching assistants (the first Mona graduates of } \\
\text { the same study) as alternative teachers-in } \\
\text { filling vacancies }\end{array}$ \\
\hline
\end{tabular}

Source: The Table prepared by the researcher.

\section{$* * * *$ Investigation Some of the benefits performance}

This description of lean production clearly indicates a number of mediating factors between lean production and benefits-kaizen.

This notion is consistent with the new inventory paradigm which emphasizes the connectedness to other processes and functions within firms and to firm profitability.

\subsection{Some of the Benefits of Kaizen [13]}
A. Process improvement.
B. Observation.
C. Use new hypotheses.
H. Reducing time (shortening time).
F. Zero investment.
E. Human Resource Development.
G. Profit and saving.

Through the foregoing and in order to employ the above mechanism, the researchers decided to adapt it to the university work environment according to Table 4.

And now we return to the focus of our research. After we got to know the different points in the traditional production system and the graceful production system in Table 3, and our fingers danced on the melodies of Kaizen, and we presented the seven wastes in the commodity manufacturing system. University and as follows [14]:

1) Not separating the lectures that consist of two hours or more, which leads 
Table 4. A suggested recruitment process for the "(What you Maintains and Maintain What you Improve)".

\begin{tabular}{|c|c|c|}
\hline Mechanism of Action & Industrial production environment & $\begin{array}{l}\text { Service production environment } \\
\text { (university education environment) }\end{array}$ \\
\hline Go to the work site & Go to the factory site & Go to the university's website \\
\hline Clean yourself & Clean your workplace & Put on your college uniform and keep your looks on \\
\hline $\begin{array}{l}\text { Do not sit in a place other than your } \\
\text { workplace }\end{array}$ & $\begin{array}{l}\text { Don't sit with others to occupy them and } \\
\text { occupy yourself for work }\end{array}$ & $\begin{array}{l}\text { Don't sit losers and sit in the library, laboratories and } \\
\text { study benches. "As the poet says in his poem," Do not tie } \\
\text { the scabies around True for fear "for that True is an } \\
\text { experiment" }\end{array}$ \\
\hline $\begin{array}{l}\text { Do not ask about the ideas put forth } \\
\text { by geniuses }\end{array}$ & $\begin{array}{l}\text { Do not oppose the implementation of rational } \\
\text { decisions }\end{array}$ & $\begin{array}{l}\text { Ask the professor what you want to ask about, but don't } \\
\text { waste time with trivial questions }\end{array}$ \\
\hline $\begin{array}{l}\text { Look for waste (Muda) any surplus } \\
\text { activity which means that less } \\
\text { (MUDA)equals a happy customer }\end{array}$ & $\begin{array}{l}\text { Find new ways to get rid of wasted resources } \\
\text { and call your boss's attention to your hard work } \\
\text { in the lab }\end{array}$ & $\begin{array}{l}\text { Get rid of outdated ideas and take the opportunity to } \\
\text { update them for the better by using advanced educational } \\
\text { methods such as computers and the Internet that reduce } \\
\text { time, effort and research }\end{array}$ \\
\hline $\begin{array}{l}\text { I look for (Mura), speak sometimes, } \\
\text { talk in some places, talk to some } \\
\text { people }\end{array}$ & $\begin{array}{l}\text { All operations must be controlled, and some } \\
\text { departments may not be left behind in the } \\
\text { performance of others, because this causes time } \\
\text { problems (delay, excess) }\end{array}$ & $\begin{array}{l}\text { All members of the faculty should adopt neutral "ways" } \\
\text { according to a scientific plan that does not allow negative } \\
\text { gaps to penetrate it }\end{array}$ \\
\hline $\begin{array}{l}\text { Search for (Muri) business } \\
\text { engagement, aggressively pushing, } \\
\text { repeat activity, redundant steps }\end{array}$ & $\begin{array}{l}\text { Look for loyalty to your job and develop your } \\
\text { skills vigorously, and train to solve difficulties, } \\
\text { and get rid of inertia in the work style }\end{array}$ & $\begin{array}{l}\text { Follow your lessons by attending, be sure to keep up with } \\
\text { the learning process, apply practical exercises in } \\
\text { laboratories, and discover smart and concise hypotheses in } \\
\text { solving puzzles and deconstructing meanings }\end{array}$ \\
\hline
\end{tabular}

Source: [16] and [17].

to poor teaching proficiency.

2) The psychological effects of students' stress due to the lack of consistent groups of learners with them.

3) Involving faculty members in job committees that do not allow them to practice and attend research activities such as conferences, seminars, workshops, and practicing the profession of profession, which are extremely important means to raise the efficiency of the faculty member.

4) Not coordinating the time of the weekly schedule in a manner that meets the requests and requirements of both the teacher and the learner.

5) Students wasted time by putting them in curricula that do not mimic their specializations, which leads to problems of not going directly into the specialty and the occurrence of the phenomenon of comprehensive knowledge incompleteness of the specialization.

6) Students are not accustomed to group work style.

7) A long time separation between the lectures of students from morning to evening, which means wastage "and interruption" at the time of achievement and the emergence of a boring spare time for the student and a waste of his time which may benefit from him in finishing his homework, or in frequenting libraries and conducting field research or practicing activities related to Educational process, but freely and with unrestricted flexibility.

In the same context, lists time wastes as follows [15]: 
1) Visitors without specific dates!!

2) Long phone calls with incomparable people.

3) Unorganized meetings and no specific agenda!

4) Waiting (the doctor's driver, your wife's appointment.

5) The occurrence of emergencies and problems that are not taken into account.

6) Losing a desire to work, and attacking boredom.

7) Stacking papers, correspondences and calls.

These practices are a vivid picture in university education that we see and see now in the field of actual specialization, and it needs to review some of the routine programs in the current education reality and give way to try to test some effective concepts such as the current topic of lean production to reach high results in the quality of university education to be ambitious. To all of them "to adapt them" side by side, along with the available energies and intellectual resources in the country, and many of them, in order to invest them properly, spread them, and prepare the means to benefit from them.

In the following discussion, the differences between Lean and Green practices will be analyzed.

The research will focus on extending the overlap of the two paradigms as analyzed in Table 5.

Table 5. Comparison of lean and green paradigms as contemporary concepts: the distinguishing attributes.

\begin{tabular}{|c|c|c|}
\hline Attribute & Lean Paradigm & Green Paradigm \\
\hline General Purpose & Maximize profits through cost reduction & $\begin{array}{l}\text { Reducing environmental risks and impacts while improving } \\
\text { ecological efficiency of organizations and their partners }\end{array}$ \\
\hline Focus & $\begin{array}{l}\text { Focus on cost reduction and increased flexibility } \\
\text { through continuous elimination of waste or NVA across } \\
\text { the supply chain }\end{array}$ & $\begin{array}{l}\text { Focus on sustainable development and the reduction of } \\
\text { ecological impact of industrial activities through elimination of } \\
\text { resource waste and pollution }\end{array}$ \\
\hline Customers & Economic customer $(\mathrm{d})$ driven by costs & Profit, People and the Planet (triple bottom line) \\
\hline Waste Reduction & Vision and strategy, Innovation, Partnerships, & Product Redesign, Process Redesign, Substitution, Prolong Use, \\
\hline Techniques & $\begin{array}{l}\text { Operations, Support functions 'Wastes: Elimination of } \\
\text { waste in all operational processes, internally and } \\
\text { externally, that arise from overproduction, waiting, } \\
\text { transportation, inappropriate processing, defects and } \\
\text { unnecessary inventory and motion }\end{array}$ & $\begin{array}{l}\text { Disassembly, Remanufacturing, Reduce, Consume by-products } \\
\text { internally, Returnable Packaging, Waste Segregation, Recycling, } \\
\text { Spreading Risks, Creating Markets, Alliances }\end{array}$ \\
\hline Principal Tool & $\begin{array}{l}\text { Value Stream Mapping: deep understanding of all the } \\
\text { processes required to bring a product to market }\end{array}$ & $\begin{array}{l}\text { Life-Cycle Assessment: deep understanding of all the processes } \\
\text { required to bring a product to market considering product } \\
\text { design, product use and end-of-life management }\end{array}$ \\
\hline Business Results & $\begin{array}{l}\text { Quality, Cost, Delivery (QCD), Customer Satisfaction, } \\
\text { Profitability }\end{array}$ & $\begin{array}{l}\text { Quality, Cost, Delivery (QCD), Customer Satisfaction, Market } \\
\text { Position, Reputation, Product Design, Process Waste }\end{array}$ \\
\hline Tools/Practices & $\begin{array}{l}\text { VSM Inventory minimization, Higher resources } \\
\text { utilization rate, Information spreading through the } \\
\text { network, JIT, Shorter lead times }\end{array}$ & $\begin{array}{l}\text { Sustainable VSM Efficiency of resource consumption, Reduction } \\
\text { of redundant and unnecessary materials, Waste (energy, water, } \\
\text { raw materials and non-product output) minimization, } \\
\text { Reduction of transportation lead time, Reduction of } \\
\text { replenishment frequency, Integration of the reverse material and } \\
\text { information flow in the SC, Environmental risk sharing }\end{array}$ \\
\hline
\end{tabular}


This is done in order to show that, although differences exist, the two practices are not incompatible.

The analysis will explain the reason for the differences and indicate a way how the two paradigms can be connected [17].

\section{Conclusions and Recommendation}

1) There is a great possibility to make the most of the model proposed by the researcher, as in the previous Table 2 and Table 3 to adapt the graceful system that the Toyota Motor Company brilliantly sparkled into the higher education environment if the high commitment imposed by the graceful system to reduce the seven wastes and trim activities worthless and we learned from Table 5 about some important differences between Lean Paradigm and green Paradigm to understand the function of each system.

2) Through polling the opinions of arbitrators from the professors specializing in this matter, whose number is (10), it is clear that the proposed scale is stable by obtaining an alpha value of (0.88), which is high compared to its norms.

3) It is necessary to apply the proposed measure in the Ministry of Higher Education to get rid of defective and misleading student and teaching performance that hinders the superiority of the Iraqi University compared to other universities in the developed world.

4) It is important to get rid of waste by getting rid of the decisions that discuss reconsidering the return of students to their study restrictions. They are part of the defect that does not add value to the educational process in Iraq, thus eliminating waste of time and resources and reducing the depletion of state treasury funds and faculty capacity on an already failed class.

5) It is useful to preserve the safety and health of pioneering teachers by opening halls on the ground floor provided that they are dedicated to them and not to be subjected to serious physical problems that may lead to injuries that make them unable to perform their teaching tasks in the future and thus lose them as intellectual capital for colleges in which they work through going up and down. It is a traditional stair in multi-floors and high-rise buildings.

\section{Conflicts of Interest}

The authors declare no conflicts of interest regarding the publication of this paper.

\section{References}

[1] Vallespir, B. and Alix, T. (2009) Advances in Production Management System, New Challenges, New Approaches. International Conference, APMS, Brodeaux, 21-23 September 2009, 89-90.

[2] Kakuroamasaka (1996) Application of Classification and Related Methods to SQC Renaissance in Toyota Motor. Fifth Conference of the International Federation of Classification Societies (IFCS96), Kobe, 27-30 March 1996, 683-695.

[3] Jewell, B.R. (1996) An Integrated Approach to Business Studies. 3rd Edition, Long- 
man, England, 452.

[4] Al-Amry, S.M. and Al-Ghalabi, T.M.M. (2008) Administration and Business. 2nd Edition, Wael Publishing House, Amman, 611.

[5] Arab Sources. http://almadananer.net/sub/-571/n19htm

[6] APICS (2002) The Performance Advantage Volume 12. American Production and Inventory Control Society, 48.

[7] http://www.demandmade.com/terminnology.hteml

[8] http://www.naledi.org.za/fighting

[9] (2009) Production. 12. https://en.wikipedia.org/wiki/Lean

[10] Moeuf, A., Tamayo, S., Lamouri, S., Pellerin, R. and Lelievre, A. (2016) Strengths and Weaknesses of Small and Medium Sized Enterprises Regarding the Implementation of Lean Manufacturing. IFAC-PapersOnLine, 49, 71-76. https://doi.org/10.1016/j.ifacol.2016.07.552

[11] Morgan, C. and \& Murgatroyd, S. (1995) Total Quality Management in the Public Sector. Buckingham. Open University Press, London.

[12] Jeffrey, K. and Morgan, J.M. (2006) The Toyota Way in Service Academic of Management Perspectives. University of Michigan, Michigan.

[13] Neves, P., Silva, F.J.G., Ferreira, L.P., Pereira, T., Gouveia, A. and Pimentel, C. (2018) Implementing Lean Tools. Manufacturing Engineering Society 28th International Conference on Flexible Automation and Intelligent Manufacturing, Columbus, OH, 11-14 June 2018, 707.

[14] Nilsson, I. (2001) Integrating Environmental Management to Improve Strategic Decision Making. Master Thesis, Chalmers University of Technology, Sweden.

[15] Economic Forum/Administrative Sciences/Knowledge Management, 2005.

[16] Dües, C.M., Tan, K.H. and Lim, M. (2013) Green as the New Lean: How to Use Lean Practices as a Catalyst to Greening Your Supply Chain. Journal of Cleaner Production, 40, 93-100. https://doi.org/10.1016/j.jclepro.2011.12.023

[17] Harrison, J. and John, C. (1998) Foundation of Strategic Management. Ohio, USA. 